症例

急性虫垂炎様症状で発症した後腹膜囊腫状リンパ管腫の 2 例

一最近 10 年間の報告例を中心とした文献的考察一

藤田保健衛生大学船曳外科（主任：船曳孝彦教授）

落 合 正宏内村正史村岡正朗

長谷川茂松原俊樹亀井克彦

桜 井洋一 丸上善久船曳孝彦

腹部急性炎症症状で発症し，他院にて虫垂炎として手術された後腹膜リンパ管腫を 2 例経験した。症例 $1: 22$ 歳女性. 発熱, 右下腹部にて近医受診し, 圧痛, 筋性防御, 白 血球增多を認め，虫垂炎の診断にて手術施行されるも症状改善せず，その後の検査にて 腹部に賴腫認めたため当院へ転入院した。症例 $2: 30$ 歳男性. 右下腹部痛にて近医受診, その際左上腹部に豪胞性疾患認められた。 8 日後再び右下腹部痛出現し再受診, 今回は 虫垂炎の診断で手術された。 1 力月後再度腹痛, 発熱出現し, 白血球増多, 腹膜刺激症 状, 麻瘏性イレウスを認め転入院した. 両者とも入院後後腹膜襄腫の診断で再開腹を行っ たが, 赛腫壁の炎症が高度で不完全切除となった.

急性腹症で発症する本疾患についての文献的考察を加え報告する。

索引用語：急性腹症, 後腹膜硋腫状リンパ管腫

\section{はじめに}

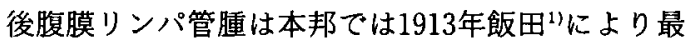
初に報告されて以来, 今日まで113例を数える比較的稀 な疾患である，本疾患は後腹膜にあって緩徐に発育す るため無症状で経過することが多く, 腹部腫瘤の触知 や圧迫症状の出現によって初めて発見されることが多 い. しかし一方では腹痛, 発熱, 白血球增多など感染 症状をもって急激に発症する例もあり，このような症 例では急性腹症や腹膜炎として緊急的に手術を受ける ため正確な術前診断は困難となる.今回われわれは腹 部炎症症状をもって発症し，虫垂炎の診断にて手術を 受けた後に症状不変あるいは悪化により転入院してき た 2 症例を経験し，若干の文献的考察を加え報告する。

$$
\text { 症例 }
$$

症例 $1 ： 22$ 墄, 女性.

主訴：発熱, 右下腹部痛.

家族歴，既往歴：特記すべきことなし。

現病歴: 平成 5 年 7 月 13 日右下腹部痛が出現し, 近 医受診した。受診時の体温 $39.7^{\circ} \mathrm{C}$, 白血球数 $14,500 /$ $\mathrm{mm}^{3}$ であり，腹部所見では臍右側にとくに強い圧痛と

1995年10月13日受付１995年12月18日採用
筋性防御を認めた．急性虫垂炎との診断で虫垂切除術 が行われたが, 術中所見では虫垂に明らかな炎症所見 を認めず, 術創から検索し得た限りでは他に病巣を認 めなかった。しかし術後も腹痛, 発熱, 白血球增多が 持続したため, 腹部超音波, CT にて検查したところ右 季助下を中心とする後腹膜腔に襄胞性疾患を認め, 同 年 7 月25日本院へ紹介入院となった。

入院時現症：腹部は平坦, 軟. 右下腹部に手術痕, 㗏右側に軽い压痛と抵抗を触知する。腫瘤は触知せず。

入院時検查成績：血液検查では異常所見なし.

腹部超音波検查（図 1 上)：右腎前面, 膵頭部後面を 中心として大きさ約 $9 \times 6 \times 5 \mathrm{~cm}$ の低エコーの腫瘤を 認めた。辺緑は整で内部は比較的厚い隔壁により honey comb 状を呈する多房性の裹胞を形成してい た.

腹部 MRI : 右上部後腹膜腔に拡がって T1強調像 では low intensity areaを, T2強調像では very high intensity area を認め, いずれも内部に隔壁様構造を 認めた。

腹部 CT (図 1 下)：同部位に隔壁を有する low density mass を認めた。

このほか上部, 下部消化管造影, 胆道造影, 腎孟尿 

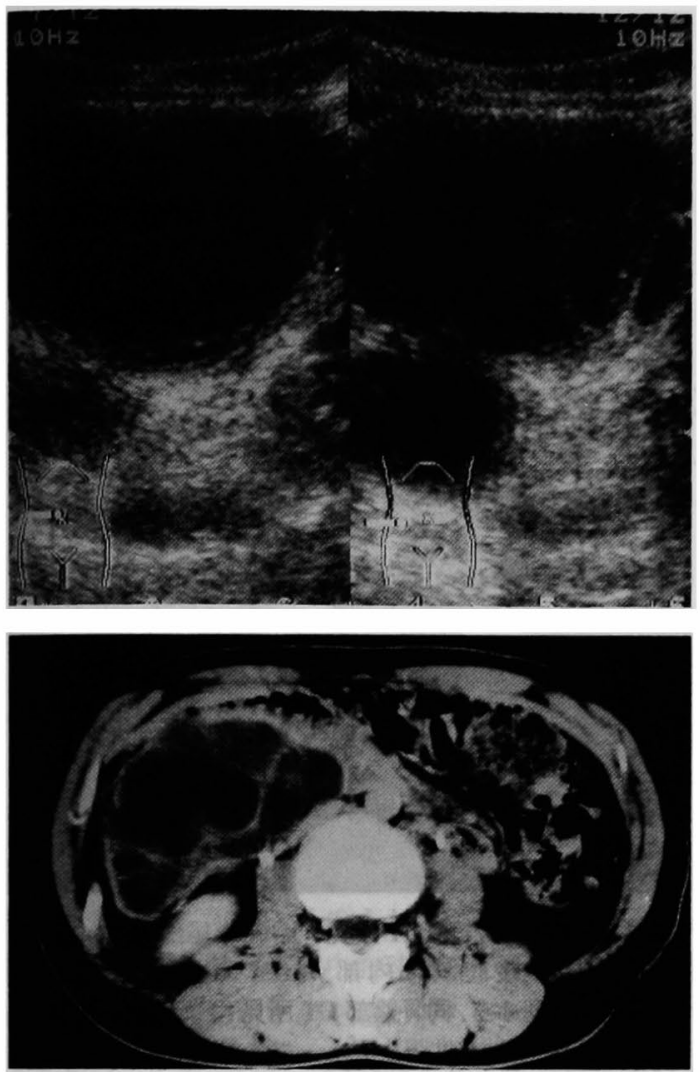

図 1 症例 1 の超音波所見（上：右季脇下に内部 very low echoic で比較的厚い隔壁により境された 辺縁性の腫瘤像を認める. 同腹部 CT 所見 (下)：膵 頭後部右腎前面に隔壁により多房性を示すlow density mass を認める。

管造影，腹部血管撮影を行ったが，いずれも圧排性の 所見のみであった。

以上より右腎門部, 膵頭部後面を中心とする後腹膜 腔より発育した多房性の襄胞性疾患の診断にて手術を 施行した.

手術所見：開腹すると十二指腸下行脚および膵頭部 の後面, 右腎門を中心に腫瘤を認めた. 周辺臟器への 炎症性癒着が高度で境界不明瞙であり, 膵頭部への強 固な癒着の一部を残し摘出した. 切除に際し襄胞腔よ り乳糜の流出をみた。

摘出標本所見（図 2 上）：10 $\times 5 \times 5 \mathrm{~cm}$ の多房性襄胞 で，壁は炎症性に硬化，肥厚していた。

病理組織所見(図 2 下) : 大小多数の襄胞の集族から なり, 内腔面は一層の内皮細胞に覆われていた。豪胞 壁に不規則な平滑筋, リンパ球浸潤を認め, リンパ管
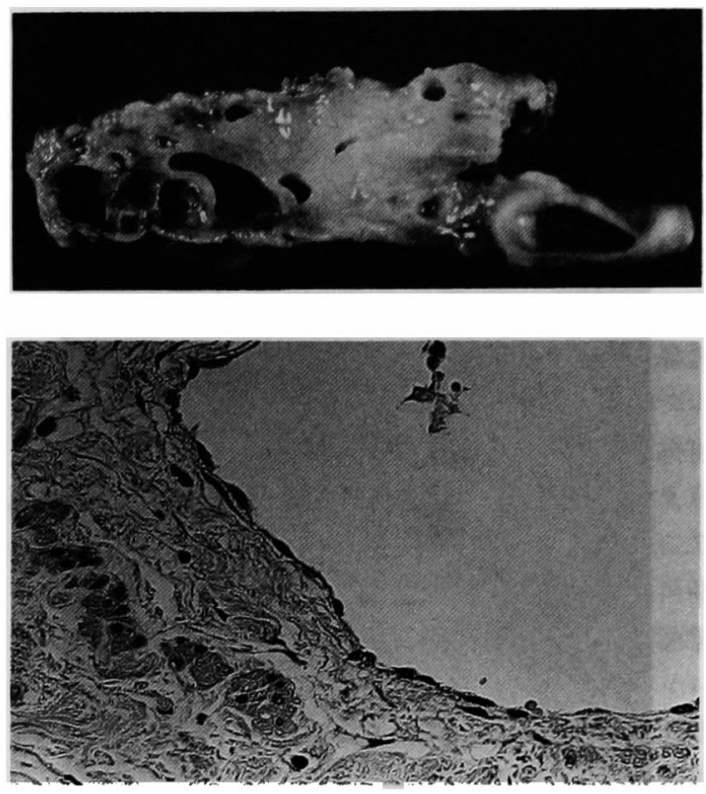

図 2 症例 1 の切除標本肉眼所見（割面）(上：大小 多数の襄胞の集合した形態を示し，壁は慢性炎症に より高度に肥厚している.同病理組織所見(下)：桽 胞内腔面は 1 層の内皮細胞によって覆われ, 壁面に は不規則に肥厚した平滑筋やリンパ球の浸潤を認め

る (HE 染色, 強拡大).

腫と診断された。

症例 $2: 30$ 歳, 男性.

主訴: 腹部膨満感。

家族歴, 既往歴：特記すべきものなし.

現病歴: 平成 6 年11月 7 日右下腹部痛出現し虫垂炎 の診断で近医に入院した. 入院時左上腹部に $17 \times 11 \mathrm{~cm}$ と大きな襄胞を認め, 経皮的穿刺により $600 \mathrm{ml}$ の内容 液を吸引した。右下腹部痛は保存的治療にて軽快した ため11月21日退院した。平成 6 年11月29日右下腹部痛 が再度出現し同院受診, 11月30日虫垂切除術を受けた が虫垂に炎症所見はほとんどなかった.しかし平成 7 年 1 月 6 日夜間突然に腹部全体の疼痛出現し同院入 院, WBC $29,900 / \mathrm{mm}^{3}$ と上昇, 腹部 X 線検査にてイレ ウス像を認めた.イレウス管挿入し保存的治療を行っ たが症状改善せず, 1 月11日本院へ紹介入院となった。

入院時現症：腹部は膨満し腸蠕動音は聴取せず。腹 部全体に圧痛, 筋性防御, 反跳痛を認めた。腫瘤は触 知せず. 右下腹部に手術痕.

入院時検査所見: 血液検査所見では白血球数 $14,000 / \mathrm{mm}^{3}$, CRP $17.2 \mathrm{mg} / \mathrm{dl}$ と高值を示したが他は 異常を認めず. 


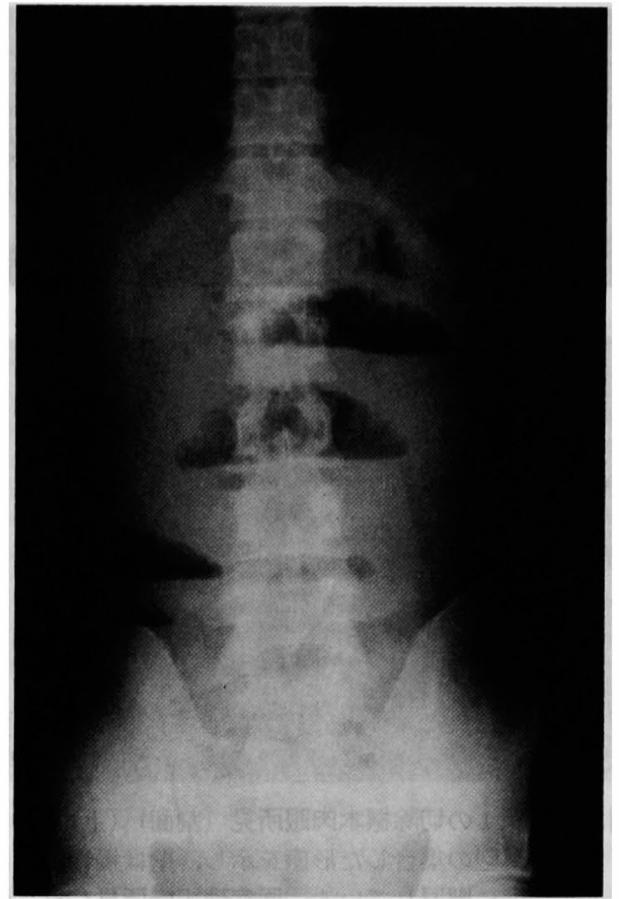

図 3 症例 2 の腹部単純 $\mathrm{X}$ 線所見（立位）: 近医受診 時の所見で, 複数の拡張した小腸ループを認め, 麻 痺性イレウスの所見である。

腹部単純 $\mathrm{X}$ 線検査（図 3 ）：拡張し二ボーを形成し た複数の小腸ループを認めた。

腹部 CT (図 4)：膵体尾部近傍に $10 \times 6 \mathrm{~cm}$ 大の隔壁 を有する water density mass を認めた。また腹水，胸 水の貯留, 腹部全域の腸管壁の肥厚と腸管腔の拡張も 認めた。

腹腔穿刺：腹腔内より膿性腹水を採取した。

以上より後腹膜㖣胞性疾患, 沉発性腹膜炎, 麻痺性 イレウスの診断で緊急手術を施行した，上腹部正中切 開にて開腹したところ，腸管を被覆した大網と腸管相 互間に隔絶された腹水と白苔の付着を諸処に認め，こ れを開放吸引した。汎発性腹膜炎の所見であり，虫垂 切除部を含め全腸管の検索したが，腸管壁には穿孔等 腹膜炎の原因と考えられる所見を認めなかった．左上 腹部膵尾部頭側の後腹膜腔に多房性の襄胞性腫瘤を認 め，聂胞壁淡症性に大網，膵，脾，腹壁に高度に癒 着していた。襄胞内容は淡黄色漿液性で, 細菌培養に 提出したが，後に細菌陰性と判明した。炎症高度のた め一部を残し可及的に切除した。

病理組織所見：症例 1 と同様薄い一層の内皮細胞に 覆われた多房性の褧胞で,リンパ管腫の診断であった。
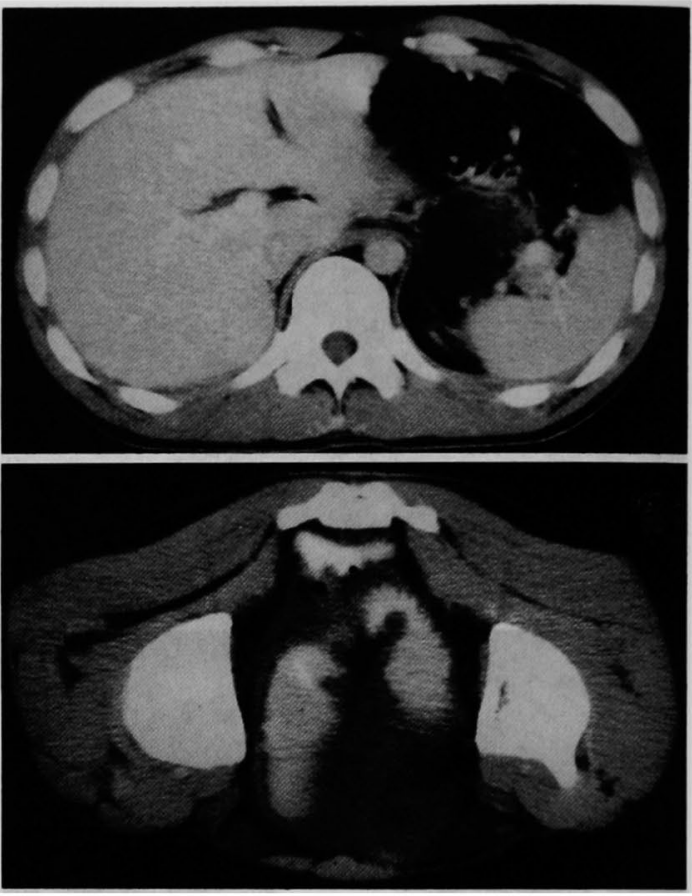

図 4 症例 2 の腹部 CT 所見 (上)：膵尾部下緑, 脾門 部近傍の後腹膜に内部 water density $の$ cystic mass を認める. 同骨盤部 CT 所見(下)：小骨盤腔に は壁の肥厚した拡張小腸ループを認め，周囲に淩出 液を認める。

\section{考案}

本邦における後腹膜リンパ管腫は植阪らがが1984年 までに 74 例を集計しているが，以後現在までの 10 年間 には39例の報告があり,自験 2 例を含めれば115例とな る. 特に最近の 10 年間の報告数が急増しているが,こ のことは CT, 超音波などの検査法の進歩, 普及と無縁 でないであろう。

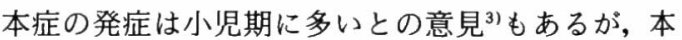
邦においては10代と50歳以上にやや少ないほかは各年 齢層にほほ均等に分布している，本症の成因は現在の ところ胎生異常説が有力であり ${ }^{213)}$ ，成因からみると小 児期の発見が多いはずと考えられるが，囊腫の増大は 一般にかなり緩徐であり，感染や出血を合併しない限 り無症状に経過することが多いため見逃されやすいと 思われる.したがって臨床症状では腹部腫瘤, 腹満感 が最も多く認められ，主訴のうちの半数以上を占めて いた(表 1)。腹痛は主訴の 2 番目に多く, 発熱がこれ に次ぐが，最近の 10 年では発熱症例の増加が目立つ. 腹痛の原因としては感染, 出血, 圧迫症状などが挙げ 
表 1 主訴と術前診断

\begin{tabular}{|c|c|c|c|}
\hline 主 & 1984まで & 1985以降 & 計 \\
\hline 腹部隀留，腹痛 & 42 & 20 & 62 \\
\hline 腹痛 ～～～～～ & 23 & 15 & 38 \\
\hline 下湤，便秘など & 8 & 0 & 8 \\
\hline 発熱 & 7 & 11 & 18 \\
\hline 腰痛, 背部痛 & 4 & 1 & 5 \\
\hline 䋃径部，陰嚄腫大 & 3 & 0 & 3 \\
\hline なし & 3 & 6 & 9 \\
\hline 術前診断 & 1984まで & 1985以降 & 計 \\
\hline 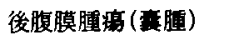 & 38 & 29 & 67 \\
\hline 腹腔内腫演 (咅腫) & 9 & 0 & 9 \\
\hline 腸管膜萎腫 & 3 & 0 & 3 \\
\hline 急性腹症 (虫垂炎含む) & 6 & 5 & 11 \\
\hline 単径ヘルニフ & 3 & 0 & 3 \\
\hline その他 & 6 & 2 & 8 \\
\hline 不明 & 9 & 5 & 14 \\
\hline 計 & 74 & 41 & 115 \\
\hline
\end{tabular}

・植阪ら゙による

られる. しかし最近10年の報告例41例でみると腹痛で 発症したのは17例で，そのうち12例が発熱を伴い, 記 載のない 1 例を除き全例白血球增多を認めていて, 感 染に由来する腹痛が 7 割を越え最も多い(表 2$)$ 。これ らの症例では筋性防御や反跳痛などの腹膜刺激症状も 呈した例が多く，初診時診断は腹膜炎とされているも のが多かった．また術前に腫瘤を触知したものは17例 中 6 例にすぎず，筋性防御などの腹膜刺激症状により 腫瘤の存在がマスクされたものと考えられた.
腹痛で発症した症例のうち急性腹症あるいは虫垂炎 として緊急あるいは準緊急的に開腹されたのは自験例 を含め 5 例（33\%）あり，発熱，白血球增多を伴う症 例の $42 \%$ を占めた。急性腹症で開腹される頻度は 1984 年以前と以降で比較してもあまり変わっていない（表 1).

感染症状で発症した12例の辜胞内容をみると, 墏液 性 4 例, 乳糜 3 例, 血性 1 例, 不明 4 例であり, 膿性 という報告はない．また内容液の細菌学的検索につい ての報告もないため証明することは難しいが，感染は 比較的短期間で消長する一過性のものが多いと考えら れる.自験例はいずれも急性虫垂炎の診断で他院にて 手術を受けたのち転院してきた症例で, 症例 1 は再開 腹時毫胞壁の慢性炎症が高度に認められたが, 細菌学 的な検索は行わなかった。症例 2 は術後の麻㿉性イレ ウスで再開腹し汎発性腹膜炎の所見であったが，同時 に採取した震胞内容の培㽰では菌は検出されず腹膜炎 との因果関係を証明することはできなかった。しかし 両者とも初回手術においては虫垂には臨床症状を説明 するほどの炎症所見はなく, 腹痛の原因はやはりリン

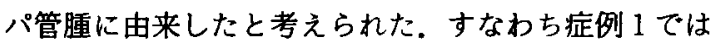
壤腫の主体は右季肋部であったが，尾側に向かって発 育し，炎症の範囲が右側腹部に及んでいたため粉らわ しかったと考える。症例 2 では襄腫は左上腹部が主体 であったが，腫瘤は非常に大きく，初発の右下腹部痛 は結腸の圧迫症状によると考えられる. その後に発症 した汎発性腹膜炎の原因については解釈が難しく結論

表 2 媵痛で発症した後腹膜リンパ管萱腫（最近10年）

\begin{tabular}{|c|c|c|c|c|c|c|c|c|}
\hline 発表年 & 発表者 & 年业 & 性 & 腫瘤触知 & 白血球 $\uparrow$ & 発勢 & 術 前 診 断 & 黄胞内容 \\
\hline 1985 & 犬房ら" & 19 & 男 & + & + & + & 急性腹症 & 暗赤色獎液性 \\
\hline 1985 & 近藤ら5) & 20 & 男 & + & - & - & 後腹膜美腫 & 不明 \\
\hline 1987 & 黑川ら6) & 44 & 男 & - & + & + & 膵頭部または後腹膜腫暍 & 乳糜 \\
\hline \multirow[t]{2}{*}{1988} & 相馬ら” & 37 & 男 & + & + & + & 後腹膜苇腫 & 血性 \\
\hline & 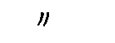 & 50 & 男 & - & - & - & 膵衰胞 & 淡褐色槳液性 \\
\hline 1988 & 河口ら & 4 & 男 & - & + & + & 急性虫垂炎 & 不明 \\
\hline 1988 & 久田ら"1 & 5 & 男 & + & + & + & 後腹膜葆腫または血楼 & 不明 \\
\hline 1988 & 猿田 ${ }^{(0)}$ & 49 & 男 & + & - & - & 記載なし & 黄褐色透明 \\
\hline 1988 & 石井ら ${ }^{11)}$ & 15 & 男 & - & + & + & 後腹膜重腫 & 谈黄色墏液性 \\
\hline 1988 & 村上ら & 8 & 男 & - & + & + & 急性腹症 & 乳糜 \\
\hline 1989 & 初瀬ら & 19 & 女 & + & + & + & 後腹膜 & 墏液性 \\
\hline 1989 & 山形ら & 5 & 女 & + & + & + & 後腹膜リンパ管腫 & 不明 \\
\hline 1991 & 飯田ら & 8 & 女 & - & - & - & 後腹膜血腫 & 血性 \\
\hline 1991 & 藤間ら ${ }^{(6)}$ & 42 & 女 & - & - & - & 後腹膜西腫 & 乳糜 \\
\hline 1993 & 赤池ら & 58 & 男 & - & & + & 記载なし & 不明 \\
\hline \multirow[t]{2}{*}{1995} & 自験例 & 22 & 女 & - & + & + & 急性虫垂炎（他院） & 乳糜 \\
\hline & " & 30 & 男 & - & + & + & 急性虫垂炎 (他院) & 谈黄色漿液性 \\
\hline
\end{tabular}


は出せないが, 初回入院時の穿刺による内容液の漏出 が二次感染を起こしたか, あるいは感染が先行しその 後自然破裂したかの可能性は考えられるであろう. おわりに

急性腹部炎症症状にて発症し, 急性虫垂炎として手 術を受けた後腹膜リンパ管腫の 2 例を報告した. 本疾 患は比較的稀な疾患てはあり多くは無症状に経過する というものの, 時に急性腹症を呈することもあり,こ の場合正確な術前診断は困難となる。急性腹部炎症性 疾患の診療に際しては,このような症例の存在も念頭 におく必要があろう。

\section{文献}

1）飯田庄八：腹膜後部萲腫の 1 例. 日外会誌 14 : $277-286,1913$

2) 植阪和修, 过毅, 森本悟一他：後腹膜董状リン 八管腫の 1 例. 外科診療 $29: 107-111,1987$

3）松田泰次, 久保玲子, 森川栄司他：後腹膜衰胞状リ ンパ管腫の 2 例. 外科診療 $29: 247-252,1987$

4）犬房晴彦, 山内 一, 和田英一他：急性腹症を呈し た後腹膜リンパ管腫の 1 例. 岥阜大医紀 $33: 242$ $-243,1985$

5）近藤 博, 森 利光, 熊谷明史 他：巨大な後腹膜 lymphangioma $の 1$ 症例. 日蹊外医会誌 46 : 1023,1985

6) 黒川善栄, 神谷順一, 桐岡智二他：膵頭十二指腸切 除術にて切除し得た後腹膜リンパ管腫の1例。日 外会誌 $88: 222-226,1987$

7）相馬光宏, 北川重幸, 岡野重幸他：：後腹膜リン
パ管腫の 2 例. 臨放線 33: 1147-1150, 1988

8）河口 剛,木村泰三, 瀧島常雄：腹痛を主訴とした 小児後腹膜リンパ管腫の 1 例. 日臨外医会誌 49 : 1109,1988

9）久田正純,成田 洋,鉿木達也他：急性腹症にて発 症した後腹膜リンパ管腫の 1 例. 日小児外会誌 $24: 1552-1553,1988$

10）猿谷真也, 功刀正史, 黒沢元博：巨大後腹膜强胞性 リンパ管腫の 1 例と本邦報告69例の検討. 絰合臨 $37: 382-386,1988$

11）石井 博, 本田善九郎, 丸山正薫他：急性腹症にて 発症した後腹膜咅状リンパ管腫の 1 例. 埼玉医会 誌 $22: 1090-1094,1988$

12）村上厚文,小泉和夫, 小泉蓉子：腹部鈍的外偒を契 機として発見された後腹膜莗胞性リンパ管腫の1 例. 昭和医会誌 $48: 281-285,1988$

13）初瀬一夫, 柿原 稔, 玉熊正说：腹部腫瘤の超音波 診断（3）一後腹膜リンパ管腫とその類似疾患. 臨 消内科 4:433-438, 1989

14）山形健一,長島金二, 土屋博之他：激痛を伴う下腹 部腫瘤として発症した後腹膜宾腫状リンパ管腫の 幼児例。日救急医会関東誌 $10: 960--992,1989$

15）飯田則利, 矢加部茂, 朔 元則他：腹部鈍的外傷後 の出血より発見された後腹膜リンパ管腫の1 小児 例. 小児外科 $23: 100-104,1991$

16）藤間利之, 沢野 誠, 津田 寛他：後腹膜リンパ管 腫の 1 例. 日消病会誌 $88: 1038,1991$

17）赤池 康, 小島原将保：後腹膜リンパ管腫の1手 術例. 日病理会誌 $82: 326,1993$

\title{
TWO CASES OF RETROPERITONEAL CYSTIC LYMPHANGIOMA PRESENTING WITH SYMPTOMS SUGGESTIVE OF ACUTE APPENDICITIS
}

\author{
Masahiro OCHIAI, Masashi UCHIMURA, Masaaki MURAOKA, Shigeru HASEGAWA, \\ Toshiki MATSUBARA, Katsuhiko KAMEI, Yoichi SAKURAI, \\ Yoshihisa MARUGAMI and Takahiko FUNABIKI \\ Department of Surgery, Fujita Health University School of Medicine
}

Two cases of retroperitoneal cystic lymphangioma which developed similar symptoms to acute appendicitis at their onsets and were operated on with a diagnosis of appendicitis at the other hospitals are reported.

Case 1: A 22-year-old female visited another hospital because of a fever and right lower quadrant pain. Regional tenderness and muscle defense were noted. Leucocytosis was marked. She underwent surgery under a diagnosis of appendicitis but her illness persisted. Later, CT and ultrasonography revealed a large cystic mass in her retroperitoneum. Case 2: A 30-year-old man was seen at another hospital because of right lower quadrant pain when a cystic lesion in the left upper abdomen was confirmed. Eight days later he had a right lower abdominal pain again and was operated on with a diagnosis of appendicitis, but only slight inflammation was noted in his appendex. One month later he again developed severe abdominal pain with peritoneal irritation and bowel paralysis.

Both patients were transferred to our hospital and underwent second operation with the diagnosis of retroperitoneal cystic disease. Histological study of the resected specimens revealed cystic lymphan. gioma. 